\title{
MARKET RETURNS TO ACQUIRERS OF SUBSTANTIAL ASSETS
}

\author{
By \\ Ray da Silva Rosa* \\ Thuy Nguyen** \\ Terry Walter\#
}

\begin{abstract}
Does poor post-acquisition performance characterise firms that make non-M\&A acquisitions? We investigate the wealth effects of substantial asset acquisitions (ie, acquisitions that cost over $\$ 10$ million) on acquiring firms' shareholders. We find significant abnormal positive market reaction to asset acquisition announcements but abnormally poor performance over the long-term post-acquisition. However, firms that acquire purely physical assets exhibit unexceptional performance. Our findings are robust to the research method weaknesses common to many studies of long-term performance and we control for free-cash-flow as well. Our results indicate that the anomalous drift in abnormal returns post-acquisition is a robust phenomenon beyond the takeover market and adds to the impressive body of research that show market prices can take a considerable period of time to reflect value relevant information. Investors' ability to exploit the apparent anomaly remains an open question.
\end{abstract}

* UWA Business School, University of Western Australia and SIRCA Limited. Email: ray.dasilvarosa@uwa.edu.au

** Macquarie Bank Limited

\# School of Banking and Finance, University of New South Wales and CMCRC Limited 


\subsection{Introduction}

Asset acquisitions are frequent and economically significant events. In Australia alone, more than ten thousand asset acquisitions took place during the 1990s. The number of asset acquisitions with a deal value of greater than $\mathrm{A} \$ 10$ million, which took place over the period extending from 1995 to 1999 , substantially exceeds the number of takeovers ${ }^{1}$. However, despite their evident economic importance, substantial asset acquisitions have received little academic attention and the wealth effect of asset acquisitions on shareholders of acquiring firms is not wholly understood.

We address two questions: (a) Is there a significant market reaction to announcements of substantial asset acquisitions? And, (b) do the acquirers experience predictable abnormal performance post-acquisition? Answers to these questions are interesting in light of widespread evidence that announcement period returns to acquirers in takeovers are generally insignificant and that their post-acquisition performance is abnormally poor, on average. Evidence of similar returns to acquirers of substantial assets indicates that the anomalous drift in abnormal returns is a robust phenomenon beyond the takeover market and adds to the impressive body of research that suggests the market may take a considerable period of time to absorb value relevant information $^{2}$.

Not everyone is convinced that markets are inefficient to the extent implied by some of the research to date (eg, Fama 1998), nevertheless, our results show that abnormally poor postacquisition performance is present even in the case of assets acquisitions. While more work remains to be done, our results are consistent with companies either systematically over-paying for assets that are difficult to value or underestimating the degree of difficulty in integrating assets with a high intangible component. Importantly, our research method incorporates controls for the now well-known biases and problems in evaluating long-run performance.

\footnotetext{
${ }^{1}$ Over the period 1995-1999, there were a total of 572 asset acquisitions made by ASX listed companies where the transaction value is equal or greater than A $\$ 10 \mathrm{~m}$ compared to 193 takeovers of publicly listed targets. While the total value of asset acquisitions did not necessarily exceed the value of assets acquired in of takeovers, the comparison shows that asset acquisitions are frequent and economically significant events.

${ }^{2}$ For instance, Rau and Vermaelen (1998) show that glamour bidders under-perform value bidders, after controlling for the effects of method of payment and form of acquisition. In Australia, Da Silva Rosa, Izan, Steinbeck and Walter (2000) show that acquirers who offer equity exhibit negative post-acquisition returns in the long-term while acquirers who offer cash experience unexceptional returns. This is after controlling for the biases known to affect estimates of long-run performance.
} 
The rest of the paper proceeds as follows. Section 2 shows how our research fits the literature. Given the extensive body of work on M\&A activity, we focus on the salient findings on sharemarket returns to acquirers in takeovers to show how they condition our expectations about the returns to acquirers of substantial assets. Section 3 describes the data and research method. Section 4 details and discusses the results. A summary and conclusion comprise section 5

\subsection{Sharemarket returns to acquirers: salient findings}

\subsection{Pre-bid performance}

Empirical evidence consistently shows that most firms that make a takeover bids have a recent history of exceptional performance (Asquith 1983, Walter 1984, Bishop, Dodd and Office 1986, and Schwert 1996). Roll (1986) observes good performance in the pre-bid period is consistent with the hubris hypothesis, that acquirers with a history of good performance suffer from excessive confidence and therefore overpay for their target firms. However, positive pre-bid abnormal returns are also consistent with the argument that managers who have performed well in the past do so because of superior managerial skills (Morck, Shleifer and Vishny 1990) and look to takeovers as a profitable avenue of investing their surplus funds (Dodd, 1980). There is no reason why this should not also apply to the acquisition of substantial assets. Firms that are performing well are more likely to seek out new investments irrespective of the investment being in the form of a listed company or other assets. In short, the evidence to date gives rise to a strong expectation that firms acquiring substantial assets are likely to be firms that have performed exceptionally well.

\subsection{Announcement period returns}

Although target shareholders gain from takeover announcements (Jensen and Ruback 1983, Jarrell, Brickley, and Netter 1988, Da Silva Rosa 1994), this is less clear for shareholders of the acquiring firms. Average returns to bidding shareholders are at best slightly positive in some studies, and significantly negative in other studies (Morck, Shleifer and Vishny 1990).

Jarrell, Brickley and Netter (1988) observe that there has been a secular decline in the returns to bidding firms over the 1960s, 1970s and 1980s and posit that part of the reason is the passage of legislation which has strengthened the bargaining position of targets and increased competition among bidders. Bradley, Desai and Kim (1988) report evidence consistent with this hypothesis. They document a significantly positive average abnormal return to 236 acquirers. However, they 
find the positive returns only accrued to shareholders of acquiring firms in single-bidder tender offers.

The largely unexceptional returns to bidders on announcement of a takeover is not confined to US bidders. Australian studies by Walter (1984) and Bugeja and Walter (1995) also report similar results. It is significant then that Australian law on takeovers for listed companies is similar to the US regulations that promote auction-style contests.

Given that takeover regulations make it difficult for acquirers to capture any economic rent, it may be that returns on announcement of takeovers of private companies and of new capital expenditures provide a more accurate pointer to the returns we can expect when firms announce substantial asset acquisitions.

Da Silva Rosa, Limmack, Supriadi and Woodliff (2001) document that successful bids for private targets in Australia are associated with significantly positive abnormal returns to bidders over the announcement period. They conclude that lower competition for private targets allows acquirers to capture more of the economic rent from takeovers. It is reasonable to presume that the market for substantial asset acquisitions is characterised by about the same level of competition as the market for unlisted private target companies.

Several studies examine the market impact of announcements of new capital expenditures and they all report a significantly positive market reaction, on average (McConnell and Muscarella 1985, Woolridge 1988, Szewczyk, Testsekos and Zantout 1996, Chen and Ho 1997, and Chung, Wright and Charoenwong 1998). However, there is significant variation in market reaction and the two main explanations that have been advanced are the growth opportunities hypothesis and the free cash flow hypothesis. These are discussed next.

The growth opportunities hypothesis is that firms with higher growth opportunities are more likely to have positive NPV projects. Support for the hypothesis comes from Chung, Wright and Charoenwong (1998), who review the association between Tobin's $q^{3}$ and market reaction to capital expenditure decisions. They find that for firms with high Tobin's $q$, the decision to increase capital expenditure results in a significantly positive abnormal return but for firms with low Tobin's $q$, increased capital expenditure results in negative abnormal returns. Brailsford and Yeoh (2000) also examine the valuation effect of capital expenditure announcements by Australian listed firms. Using Signal-G data they identify 170 announcements of expenditure on 
physical assets made between July 1995 and December 1997. Brailsford and Yeoh find that acquiring firms earn insignificant announcement period returns. However, when they partition their sample on the basis of growth opportunities (proxied by the market-to-book ratio), they find support for the investment opportunities hypothesis. Firms in the highest market-to-book quartile experience, on average, significantly positive returns. On the other hand, firms in the lowest market-to-book quartile experience significantly negative abnormal returns. Brailsford and Yeoh conclude that the market reacts positively to the capital expenditure announcements made by firms with high growth opportunities.

Another variable that conditions the market reaction to acquisitions is "free cash flow". Jensen (1986) defines free cash flow is any "cash flow in excess of what is required to fund positive NPV projects" (Jensen 1986). Thus, any acquisition by firms with free cash flow is, by definition, a negative NPV project. The presence of free cash flow is a manifestation of an agency problem because the excess cash is not returned to the shareholders. Brailsford and Yeoh (2000) report that firms with high level of cash flow and low growth opportunities experience a significant negative abnormal return of $2.002 \%$ when announcing capital expenditure.

\subsection{Post-acquisition returns}

Unlike the announcement period returns, the evidence on post-takeover performance is more consistent, with a clear majority of studies indicating a downwards drift in bidder performance (Jensen and Ruback, 1983, Bradley, Desai and Kim, 1983; Agrawal, Jaffe and Mandelker, 1992; Loughran and Vijh, 1997, Da Silva Rosa, Izan, Steinbeck, and Walter, 2000).

Controlling for the now widely acknowledged biases in assessments of long-term sharemarket performance significantly ameliorates the secular decline in post-acquisition performance (Brown and Da Silva Rosa 1998) and it is reasonable to conclude that the under-performance documented in earlier studies has been over-stated. However, post-bid under-performance in the long-term remains predictable for some acquirers such those who offer shares rather than cash (Da Silva Rosa, Izan, Steinbeck and Walter 2000) and "glamour" acquirers (ie, acquirers with a high market-to-book ratio) (Rau and Vermaelen 1998).

Agrawal, Jaffe and Mandelker (1992) observe that one possible explanation for the predictability of returns is the inability of the market to react immediately to merger events. Thus, abnormal long run post merger performance could "reflect that part of NPV of merger to acquirer which is

\footnotetext{
${ }^{3}$ Tobin's $q$ is generally defined as the ratio of market value of firm's assets to their replacement costs. It is a proxy
} 
not captured by announcement period returns" (p.1620). However, Agrawal et al find a negative relation between the market reaction to an announcement and subsequent performance. They conclude that market inefficiency is not a plausible explanation for the anomalous drift but it is not obvious why inefficiency is ruled out, particularly in light of the other evidence showing that some subsets of acquirers exhibit predictable drift in their abnormal returns. Notwithstanding this point, Agrawal et al's results indicate, if more evidence is needed, that it is not sufficient to review announcement period returns to estimate the total sharemarket consequences of acquisitive activity. A complete study must take into account long-term returns as well.

\subsection{Data and research method}

\subsection{Sources}

To identify our sample of ASX firms that made substantial asset acquisitions over the period 1 January 1990 to 31 December 1999, we rely primarily on the Signal $G^{4}$ database made available by the Securities Industry Research Centre of Asia-Pacific (SIRCA). Signal G is the most comprehensive source of company announcements in Australia. The operation of the Continuous Disclosure Regime in Australia means that the database ostensibly captures all material asset acquisitions and disposals by listed companies since it began collecting these in late 1991. The SDC Platinum database is used identify asset acquisitions announcements made prior to Signal G's operation. SDC Platinum database is a popular source of takeover data in Australia, and has been used by previous Australian studies e.g., Da Silva Rosa et al (2001).

The day end share prices for each of the listed firms in the sample are obtained from the Core Research Database (CRD) maintained by SIRCA. The daily share prices data are used to calculate the short run returns associated with market reaction to the announcement of asset acquisitions. The All Ordinaries Accumulated Index data are also obtained from CRD.

All other data are sourced from Aspect Financial. These include data on financial and operating firm characteristics such as total assets, market-to-book, and cash flow.

\footnotetext{
for growth opportunities. Firms with high Tobin's $q$ are presumed to have high growth opportunities.

${ }^{4}$ Signal G is the data feed provided by the Australian Stock Exchange (ASX) to facilitate the communication of company announcements and disclosure to brokers and investors. It is an instrument to keep the market informed of company specific developments that are value-relevant. Company announcements fed through Signal G include takeover announcements, announcements of assets acquisitions and disposals, dividends, and periodic reports.
} 


\subsection{Sample selection}

To identify firms announcing substantial asset acquisitions, we search across the entire Signal G database using keywords (eg, "acquisitions", "assets"). This keyword search yields over ten thousands announcements. Determining which announcements are relevant entails reading every announcement and we adopt the following procedure.

Several filters are applied. First, the transaction size must be greater or equal to A $\$ 10 \mathrm{~m}$. While the minimum deal size of $\mathrm{A} \$ 10 \mathrm{~m}$ is an arbitrary figure, it is imposed to ensure that only asset acquisitions of economic significance are included in the sample ${ }^{5}$. Our deal size is obtained from the Signal G acquisition announcements. Where the Signal G announcement does not contain a deal value, we use the deal value as reported in SDC.

Second, related announcements are identified and the date of the earliest related announcement is taken as the announcement date. Where both SDC and Signal G overlap, the earlier of the two dates (where they differ) is deemed the announcement date

Announcements which make passing reference to the possibility of implementing an acquisition program at some (unspecified) time in the future are excluded. We also exclude announcements relating to the option of acquiring an asset. However, announcements relating to the exercise of an option to acquire an asset are included in the sample at the date that the option is announced to be exercised. Announcements of contracts rewarded are also excluded.

Also excluded are announcements of the acquisition of an asset for the purpose of sale-lease back arrangement, as they are more in the nature of financing for the leasing firm rather than for the growth of the acquiring firm. Asset acquisitions by a subsidiary from the parent entity or vice versa are also excluded. The final sample ("full sample") contains 624 announcements of substantial asset acquisitions.

A potential problem with the full sample is that it incorporates a very broad definition of asset acquisition. A number of acquisitions are purchases of complete lines of business and include whole companies. Other announcements relate to the acquisition of shares. Given that the market may be differentially efficient in valuing these kinds of assets we apply two more filters to the full sample to derive a subset comprising pure asset acquisitions and a subset of pure physical asset acquisitions.

\footnotetext{
${ }^{5}$ A minimum deal value of $\$ 10 \mathrm{~m}$ is consistent with that employed in numerous studies.
} 


\subsubsection{Pure assets sub-sample}

This sub-sample excludes all acquisitions of financial assets, companies, businesses or divisions. Also excluded are assets acquired through mergers and takeovers. However, assets need not be tangible to be included in this sub-sample. Acquisitions of intangible assets such as brand names are also included. This results in a sub-sample of 333 announcements of substantial asset acquisitions by 184 firms.

\subsubsection{Physical assets sub-sample}

The physical assets sub-sample is a subset of the pure assets sub-sample. To be included in the physical assets sub-sample the announcement must relate to the purchase of tangible assets. Such acquisitions include purchases of plant, machinery, property, equipment, and shopping centre. Capital expenditures associated with the construction of a physical asset such as a building or new plant are excluded. Also excluded are acquisitions of assets via purchase of an interest in a joint venture. Announcements of permit, rights, distribution and acquisitions of interest in projects by mining companies are also excluded from the sample of physical asset acquisitions. However, an acquisition of a mine is regarded as an acquisition of a physical asset. The physical assets sub-sample comprises 225 announcements by 116 firms.

\subsection{Short run abnormal returns}

The short run abnormal performance of our sample firms is estimated over several periods of days centred on the acquisition announcement date. We report average abnormal returns. The abnormal return to each sample firm for a given period is calculated by subtracting the return to the All Ordinaries Accumulation Index (AOAI) from the sample firm's return expressed as a

price relative. The use of the AOAI as the proxy for expected returns is consistent with earlier Australian takeover studies (Bellamy and Lewin, 1992; Bugeja and Walter, 1995; Da Silva Rosa, Izan, Steinbeck and Walter, 2000).

The calculation of abnormal return (AR) is as follows (illustrated with reference to the period [$5,+5]$ days relative to the acquisition announcement date):

$$
A R_{i[-5,+5]}=\left(\frac{P_{5}}{P_{-6}}\right)-\left(\frac{I_{5}}{I_{-6}}\right)
$$

Where:

$\mathrm{P}_{5}$ is the share price of firm $i$ at end of day 5 
$\mathrm{P}_{-6}$ is the share price of firm $i$ at end of day -6

$\mathrm{I}_{5}$ is the All Ordinaries Cumulative Index at end of day 5

$\mathrm{I}_{--6}$ is the All Ordinaries Cumulative Index at end of day -6

Given the evidence that market reaction to announcements of asset acquisitions are conditioned by firms' growth opportunities and free cash flow we sort our samples into quartiles on the basis of growth opportunities and free cash flow. Acquiring firms are also sorted into quartiles according to relative size of the transaction to facilitate the assessment of the economic significance of the results.

\subsection{Long run abnormal returns}

Our estimates of abnormal returns over longer periods are calculated on the same basis as our short-run returns ${ }^{6}$. Note that this requires our sample firms to survive over a given period since we effectively estimate the average abnormal return to a buy-and-hold strategy. We favour the use of buy-and-hold returns because they more closely approximate the actual return to investors. To minimise the impact of survival bias, we ensure that the firms included in our market portfolio proxy also survive over the given period. For instance, Pacific Dunlop's abnormal return over the period spanning, say, June 1993 to June 1995 would be its buy-and-hold return over this period less the simple average buy-and-hold return to all firms with price data available over the full period. In short, we define the market portfolio as comprising all firms that with sufficient share price data available to calculate a buy-and-hold return over the period June 1993 to June $1995^{7}$.

The simple average buy-and-hold return to the market portfolio yields a systematically misleading estimate of the return to the market portfolio since small stocks are over-weighted. We therefore also calculate a value-weighted return to the market portfolio, using each firm's market capitalisation at the beginning of the period to weight its return. Finally, in order to control for the well-known systematic association between firm size and share returns, we calculate a third market return proxy: a size-decile return. The size-decile return for a given experimental sample firm is obtained by identifying all firms in the market portfolio with buy-

\footnotetext{
${ }^{6}$ Our approach is modelled on Brown and Da Silva Rosa (1998)

${ }^{7}$ Our method does not yield an estimate of the abnormal return to a feasible investment strategy since our experimental samples and market portfolios incorporate a deliberate "look-ahead" bias. However, this does not matter since our principal interest is not in estimating precise point estimates of abnormal return but in detecting if our experimental sample firms exhibit significant abnormal performance. Brown and Da Silva Rosa (1998) discuss this issue in more depth.
} 
and-hold returns over the given event-window, ranking them on their market capitalisation at the beginning of the event-window, sorting them into size-deciles (with decile one comprising the $10 \%$ smallest firms), and calculating the equally-weighted buy-and-hold return to the decile to which the sample firm belongs.

We test for significance using a re-sampling technique that relies on the construction of an empirical distribution of returns from 1001 control portfolios matched with the experimental portfolio on one or more attributes. To explain the construction of the 1001 control portfolios, and demonstrate the matching process, we describe the procedure assuming the event window of interest is the period spanning $[-1,+1]$ months relative to the asset acquisition announcement month. The four steps below are repeated for each experimental sample bidder that has price data over the period $[-1,+1]$ months relative to the announcement month.

1. Identify the set $\{$ LS $\}$ of all listed firms that survived over the period $[-1,+1]$ months defined relative to the sample firm's announcement month.

2. Calculate the size (i.e., price per ordinary shares at the beginning of month [-1] multiplied by number of issued shares) of each firm in set $\{L S\}$ and identify the size decile of the experimental firm.

3. Select a firm from the same size decile as the experimental firm, drawing randomly and sampling with replacement, and allocate it to the first 1001 control portfolios.

4. Repeat step 3 one thousand times, each time moving on to the next control portfolio in the sequence of 1001 control portfolios.

The performance of the experimental sample firms are then compared against the distribution of the performance measures of the 1001 control portfolios. An important advantage of this method is that significance tests are free of parametric assumptions since there is no reliance on formal test statistics.

\subsection{Findings and discussion}

Section 4 reports the sharemarket performance of firms that engaged in substantial asset acquisitions over the period 1990-1999.

\subsection{Preliminary observations}

Asset acquisitions are clearly frequent and economically significant events. Over the sample period, the aggregate dollar value invested in asset acquisitions by the sample firms exceeds 
A \$69.6bn (see Figure 1). Table 1 reveals that of the 624 asset acquisitions with a deal value of equal or greater than $\mathrm{A} \$ 10 \mathrm{~m}, 511$ occurred after 1995. This highlights the increasing popularity of asset acquisition as a form of external investment (although the figures are not deflated). This observation is consistent across the pure assets and physical asset sub-samples.

Not only do asset acquisitions occur frequently, they are also large in size. Table 2 reports an average dollar value of asset acquisition, for the full sample, of $\$ 112.654 \mathrm{~m}$. The large deal size is also present in the physical asset sub-sample, which recorded an average deal size over $\$ 88 \mathrm{~m}$ and a median close to $\$ 40 \mathrm{~m}$. Table 2 also reports the relative deal value of the asset acquisition transactions. While the figures indicate that the average size of an acquisition is approximately half the size of the acquiring firm (the relative deal size for the full sample, pure assets subsample, and the physical asset sub-sample are $45.55 \%, 51.73 \%$ and $57.09 \%$ respectively), this result is probably driven by outliers (maximum relative deal size is over 44 times the size of the acquiring firm). The typical size of asset acquisition would probably be closer to $10 \%$ of the acquiring firm's size, as suggested by the median.

\subsection{Announcement period returns}

Table 3 reports abnormal announcement returns. Consistent with our prediction that the lower level of competition in the asset market allows the acquirer to capture more of the economic gains associated with an asset acquisition, the full sample of acquirers performed significantly better than the market on announcement of asset acquisitions across all event windows. This finding is consistent with those reported in the capital expenditure literature (Woolridge, 1988; Chen and Ho, 1997; Chung, Wright and Charoenwong, 1998).

However, acquirers in the physical asset sub-sample experienced no exceptional performance over the announcement period. The significantly positive abnormal returns decreases from $1.56 \%$ (column 2), for the $[-5,+5]$ day event window, to $0.74 \%$ (column 3 ) as you move from the full sample to the pure assets sub-sample, and disappears for the physical asset sub-sample (column 4). The unexceptional performance by the physical sub-sample may be related to the fact that this sub-sample consists largely of listed property trusts. These trusts frequently buy and sell assets as part of their normal business operation. Thus, the market may anticipate the asset acquisitions by these acquirers and this may explain the lack of significant market reaction on the announcement of acquisitions. 
The higher positive abnormal performance for the full sample, compared to the pure assets subsample, suggests that some of the exceptional performance is driven by assets acquired indirectly through the acquisition of shares. This finding is consistent with the evidence in the takeover literature that cash offers for equity are view positively by the market (Jensen and Ruback, 1983).

\subsubsection{Differences in returns to firms in the top and bottom quartiles}

Tables 4 and 5 report the mean abnormal returns to firms ranked in the top and bottom quartiles on relative size of acquisition (Table 4) and on returns along with the difference in mean abnormal performance for firms acquiring substantial assets over the announcement period, comparing firms in the top and bottom quartiles for a particular characteristic. Abnormal performance is estimated over $[-5,+5]$ days.

\subsubsection{Relative size of acquisition}

The results in Table 4 indicate that the market only reacts to announcements that have a potentially significant impact on acquirer's value (Brailsford and Yeoh, 2000). Firms in the highest relative deal value quartile earn, on average, a significant positive return of $4.07 \%$ over the $[-5,+5]$ day window, while firms in the other quartiles exhibit unexceptional performance. The difference in mean abnormal returns between acquirers in the top and bottom quartiles is significant at the 0.01 level (Panel A of Table 4). This result is robust across the different return windows.

However, this result does not hold for the physical asset sub-sample. Unlike the full sample, the only event window for which the highest relative deal value quartile display exceptional performance is the $[-5,+5]$ day window. Further, Panel B of Table 4 shows that the difference in

performance between the top and bottom quartiles is not significant. The absence of a positive relationship between abnormal returns and the relative size of asset acquisition for the physical asset sub-sample is probably due the fact that, on average, this sub-sample does not experience abnormal performance over the announcement period.

\subsubsection{Growth opportunities and free cash flow}

As noted earlier, past research generates the expectation that firms with high growth opportunities will experience a significantly higher abnormal return on the announcement of substantial asset acquisition. We use the market-to-book value of total equity to proxy for growth opportunities. 
Table 5 shows that acquirers in the top market-to-book quartile do not exhibit abnormal performance However, firms in the lowest market-to-book quartile have a significant positive abnormal return of $3.34 \%$ over the $[-5,+5]$ day return window.

We investigate whether agency considerations condition the market's response to asset acquisitions by grouping firms on the basis of free cash flow. We use, as our proxy for free cash flow, undistributed cash flow defined as operating income before depreciation minus interest expense, taxes and dividends, scaled by total assets ${ }^{8}$.

Table 6 reveals that firms with highest level of undistributed cash flow significantly outperform the market over the various return windows. Over the $[-5,+5]$ day relative to announcement day, the full asset acquisition sample earn an average abnormal announcement return of $2.08 \%$. However, a similar significant positive abnormal performance $(2.01 \%)$ is also reported for acquirers with the lowest level of undistributed cash flow.

These results do not generate evidence to support or contradict the free cash flow hypothesis. It may be that undistributed cash flow is not a valid proxy for free-cash-flow. However, our results do indicate that a high level of cash flow is not necessarily penalised by the market. The positive abnormal returns of $2.08 \%$ over the $[-5,+5]$ day window for the top cash flow quartile indicates that market does not treat asset acquisition by firms with a high cash flow level as non-value maximising behaviour.

Notwithstanding the above results, the agency problems of free cash flow problem are most likely to manifest in firms with a high level of undistributed cash flow and limited growth opportunities. Thus, testing for free cash flow effect requires the investigation of the interaction of undistributed cash level and growth opportunities.

Table 7 provides the mean BHARs for each of the four cells (each cell presenting a combination of cash flow and market-to-book level) over the $[-5,+5]$ day window. Cell A of Table 7 (i.e., the interaction of high cash flow level and low market-to-book ratio), is the most likely combination that would result in a free cash flow environment. High (low) cash flow firms are firms with a cash flow ratio equal or greater (less) than the sample mean. Whereas, high (low) growth firms is defined as firms with a market-to-book value of total assets of equal or greater (less) than 1.

\footnotetext{
${ }^{8}$ Lang, Stulz and Walkling (1991) use this measure, among others, as a proxy for free cash flow. They report their results do not alter substantially when different cash flow measures are used.
} 
Contrary to the prediction of the free cash flow hypothesis, the market does not punish acquisitions by firms with free cash flow. Firms with free cash flow (i.e., observations in Cell A) outperform the market, with an average abnormal positive return of $4.99 \%$ over the $[-5,+5]$ day window. Firms in cells $\mathrm{C}$ and D also experience exceptional performance. Perhaps the most surprising finding is the insignificant return in Cell B (i.e., the combination of high growth prospect and high cash flow, which should in theory send a positive signal to the market as growth options are being exercised $)^{9}$.

The significantly positive abnormal returns for observations in Cell A is consistent with the notion that investment by firms with free cash flow may minimise the loss that investors otherwise expect as a result of the high level of free cash flow (Lang, Stulz and Walking, 1991).

\subsection{Long-run returns: pre-, post- and around acquisition announcement}

The following analysis of the long-run performance of acquiring firms is incomplete due to the non-availability, at the time of writing, of results on the distribution of control portfolio returns. However, all return data for the sample of acquiring firms are reviewed and these data are sufficiently extensive to allow us to draw a number of relevant findings that do not require comparison with the distribution of control portfolio return metrics. Further, even in the cases where comparison with the control portfolios is required to draw firm conclusions, it so happens that the results for the experimental sample are strong enough to allow us to draw provisional conclusions with reasonable confidence that future tests of significance are unlikely to overturn them.

The analysis below starts with a description of the principal features of Table 8, which summarizes our findings. A commentary on the findings and discussion of their implications follows.

\subsubsection{Principal Features of Table 8}

Table 8 includes a summary of the average performance of the acquiring firms over various event-windows expressed in months relative to the month in which each acquisition was announced. For instance, the period $[-1,+1]$ refers to the three month period centered on the announcement month. The cumulative average return to the sample firms is reported in column

\footnotetext{
${ }^{9} \mathrm{We}$ also performed another sensitivity analysis, which categorised the observations based on sample median for both cash flow and market-to-book ratio. The results, reported in Table 15 (Appendix 9.2), is essentially the same to that reported in Table 16.
} 
two, column three reports the average market (equal weighted) adjusted return to the sample firms (i.e., the average of each firm's return less the market portfolio return), column four reports the average market (value-weighted) adjusted return, and column five includes the average decile-adjusted return (i.e., the average of each firm's return less the return to the firms in its decile). Given the arguments advanced in Brown and Da Silva Rosa (1998) and elsewhere, we place most weight on the decile-adjusted results in our analysis, particularly over the wider eventwindows where the biases associated with market-adjusted results become more severe.

The 10 event-windows listed in the first column of Table 8 review performance over three distirct periods: the pre-announcement period, the announcement period and the post-announcement period. This categorization of periods is standard in event-studies of takeovers, for reasons that become clear as the results are discussed.

The last column in Table 8 includes the number of sample firms with available share return data over each event-window. It is very clear that the number of observations drops off rapidly the further away the extreme months of each event-period commence. For instance, although there are 627 firms with available data over the period $[-3,-1]$ months, there are only 166 firms over the three year period $[0,+36]$ months. The high drop-off rate would be an issue for concern if it were attributable to lack of survival of the sample firms but investigation reveals that the reason for the high drop-off rate is that our share return data extend only to December 1999 and this date falls short of the three year post-announcement period for the overwhelming majority of firms in our sample.

Note that the number of firms with available data over the period [-18,-1] is 554, which is substantially lower than the number of firms with data over $[-3,-1]$. Our monthly share return data extend back to 1974 so lack of data availability is not the explanation for the drop-off. The reason for the drop-off in the pre-announcement period is that many of the sample firms listed shortly before announcing an acquisition of substantial assets. One concern this raises is that any poor performance by our sample firms may be partly attributable to our sample containing a disproportionately high percentage of newly listed firms who exhibit the poor post-listing performance documented in many studies. We leave this question for further research.

Table 8 is divided into three panels. Panel A includes summary results for the whole sample of acquiring firms. Panel B reports summary results for firms that made acquisitions only of physical assets. Panel $\mathrm{C}$ contains results for firms that made acquisitions of all assets excluding 
physical assets. One reason for reviewing acquisitions of physical assets separately is that they are arguably easier to value and integrate into operations than non-physical assets. Given this assumption, it may be that the sharemarket is differentially efficient with respect to assessing the impact of physical and non-physical assets. As seen below, there is significant support for this proposition.

One important point needs to be borne in mind when reviewing the summary results. Brown and Da Silva Rosa (1998) note because the market and decile portfolios consist of firms that have survived over the event-window, it is not possible to interpret the market and decile adjusted returns as an estimate of abnormal performance attributable to a feasible investment strategy. The "look-ahead" bias imposed by conditioning on survival means that our measures of abnormal performance are not attainable in practice. Conditioning on survival facilitates tests relative performance because survival related biases are controlled but the abnormal returns should not be interpreted as an estimate of economic growth (or loss) attributable to the acquisition of substantial assets. For this reason, point estimates of abnormal performance over various eventwindows are not much discussed below. Only relative performance is assessed. Where point estimates are discussed, the focus is relative difference rather than absolute value.

\subsubsection{Abnormal performance - all acquiring firms}

The most striking finding from Panel A of Table 8 is that the pattern of long-run abnormal performance of acquirers of substantial assets in the pre-announcement, announcement, and postannouncement periods is similar to that documented in most takeover event-studies. That is, the acquirers outperform substantially over the months leading up to announcement of an acquisition, they exhibit positive performance over the three month period centred on the month of acquisition announcement (i.e., $[-1,+1]$ months), and experience negative abnormal performance over the post-announcement period. The decline is evident within a month so, based on the market equal-adjusted returns, and becomes more severe over time. The implications of these findings are worth dwelling on.

\subsubsection{Pre-announcement performance - all acquiring firms}

One possible explanation for the strong positive performance of the sample firms over the preannouncement period is that investors anticipate the benefits of the expansionary program that the acquirers undertake and incorporate this into share prices. However, given that exceptional performance is evidence even over the period $[-18,-1]$ when acquirers earn an average buy-and- 
hold return of $32.26 \%$ and a decile-adjusted return of $23.17 \%$, a more likely explanation is that acquirers of substantial assets are typically firms that are doing well and seek to build on that performance by expanding via acquisition of assets. Conclusive evidence of the exceptional performance of acquiring firms in the pre-bid period can only be obtained by comparing the experimental sample portfolio's return metrics with the distribution of control portfolio returns. However, in the absence of this distribution, we note that our results in line with those reported by Brown and Da Silva Rosa (1998) in their review of pre-announcement returns to acquiring firms and they employ an identical significance testing technique to conclude that their results are highly significant.

An interesting finding from Panel A of Table 8 is that the market (value-weighted) adjusted returns are consistently higher than the market (equal-weighted) adjusted returns across all eventwindows. In fact, the market (value-weighted) adjusted returns are just about always at least $100 \%$ higher than their corresponding market (equal-weighted) returns. This finding is not surprising given that over two-thirds of our sample firms are drawn from size deciles nine and ten (i.e., the two deciles comprising the largest $20 \%$ of firms over a given a period). The equallyweighted market portfolio returns tend to be driven by the extreme positive returns recorded by small firms (i.e., the well attested "size-effect") and so market (equally weighted) adjusted returns to our sample of predominantly large firms are typically much lower than the corresponding market (value-weighted) adjusted returns. However, Panel A also shows that the decile-adjusted returns are not invariably higher than the market (value-weighted) adjusted returns. Again, this result is not unexpected given that the value-weighted return to the market portfolio will be overwhelmingly influenced by the returns to the firms in the top two deciles, which is where most of our sample firms reside.

A pertinent question that has been raised in the context of takeovers is whether managers of firms that have performed well are justified in seeking to continue to outperform by engaging in takeovers. As noted earlier, Roll (1986) has argued that managers of firms doing well may well be afflicted by hubris, that is, they may over-estimate their own abilities and over-reach by expanding too rapidly. The abnormal decline in merged firms' performance over the post-bid period that has been documented in many studies is consistent with Roll's hypothesis. However, takeover event-studies have been unable to control for the role played by takeover regulations in encouraging over-payment by acquiring firms. That is, given that takeover bids for listed companies have to be open bids, the regulations encourage a public auction-like process that 
increases the probability that the winning firm will have paid too much. Acquisitions of substantial assets are not subject to the stringent public auction-inducing regulations which are enforced for takeover bids and so the hubris hypothesis can be tested more rigorously ${ }^{10}$.

\subsubsection{Announcement period performance - all firms}

Judging by the abnormal performance of the acquiring firms over the announcement period [-1,1] month (see Panel A), the sharemarket does not seem to share the belief that the managers of these firms suffer from hubris. The 587 firms with available data over this period exhibit an average decile-adjusted return of around $2.06 \%$. Once again, the significance of this finding cannot be assessed in the absence of a distribution of control portfolio returns, however, the result is in the upper range of the findings from takeover event-studies that show firms that make takeover bids experience insignificant abnormal returns. Our findings suggest that, at worst, firms acquiring substantial assets do not lose over the announcement period and that, at best, they earn a significantly positive abnormal return. The results based on daily return figures indicate that the latter interpretation is more accurate.

\subsubsection{Post- announcement period performance - all firms}

The post-announcement returns for the acquirers of substantial assets reveal a dramatic slide in their performance. The extent of the reversal of fortune can be seen by comparing the market (equal weighted) adjusted performance of the sample firms in the pre- and post-announcement periods. The market (equal weighted) adjusted returns are heavily biased against revealing positive abnormal performance from our sample of predominantly large firms but at no stage over the pre-announcement period is the average abnormal return negative. However, starting as early as the period $[0,+3]$ months, the average market (equal weighted) adjusted return is negative. Over the period between $[+12]$ months to $[+24]$ months, the slide in average abnormal performance is arrested, largely due to an outlier positive abnormal return to a single firm, but it manifests again over the period $[+24]$ to $[+36]$ months (ie, in the third year post-announcement).

This finding is strongly consistent with the hubris hypothesis - firms acquiring substantial assets over-estimate their abilities and over-pay for the assets. However, as Brown and Da Silva Rosa (1998) observe, the continuous decline in abnormal performance is unsettling for proponents of an efficient market because while a sharp downward revaluation on announcement of an acquisition is consistent with an efficient market, a slow decline in performance indicates that the

\footnotetext{
${ }^{10}$ Notwithstanding this point, it should be borne in mind that there is no compulsion on firms to make takeover bids.
} 
market takes a considerable period of time to revise its beliefs. Note that the evidence does not point to a mere slowness in market reaction. The positive response to announcements of acquisitions of substantial assets suggests that the market first wrongly estimates that the acquisitions will be value-increasing and then revises its views slowly over the long-term. In sum, the evidence implies that the market is inefficient in two respects, once in its initial assessment of the value of the acquisition and, secondly, in revising its views very slowly.

Given that the evidence indicates that acquisitions of substantial assets are, on average, negative net present value investments and that the market finds it difficult to assess the worth of asset acquisitions accurately, it is reasonable to posit that some asset acquisitions are more likely to display evidence of market mispricing than others. This line of reasoning is investigated below.

\subsubsection{Abnormal performance - acquisitions of physical \& non-physical assets}

Panels B and C show average sharemarket returns after dividing our sample of firms into those that made acquisitions comprising solely physical assets and those that made acquisitions that included intangible assets. Panel B reports the results for the acquirers of physical assets while Panel $\mathrm{C}$ includes results for all other acquirers. Our categorization is based on the assumption that physical assets are easier to value than other assets and also easier to integrate into operations. If true, our premise implies that the sample of firms comprising acquirers of physical assets will display less evidence of market inefficiency in pricing, for instance, the postannouncement period performance of these firms will be unexceptional, indicating that the effects of the acquisitions were fairly and accurately incorporated into share prices around the announcement period.

The results in Panels B and C of Table 8 reveal remarkable support for the above hypothesis. It is clearly evident from the results that the poor performance of the acquirers of substantial assets over the post-announcement period is driven principally by the performance of acquirers who have not restricted themselves to acquiring physical assets. Over the period $[0,+36]$ months, the acquirers of physical assets only earn, on average, a decile-adjusted return of $0.40 \%$, which is likely insignificant. However, other acquirers earn, on average, a decile-adjusted of $-8.24 \%$. Further, note that the announcement period returns for acquirers of physical assets is lower than the announcement period returns of acquirers of "Other" assets. Given that "Other" asset acquirers underperform in the post-bid period, this result is consistent with both the managers and

Further, it is not obvious why the market should take so long to penalise the hubristic managers. 
sharemarket investors over-estimating the gains from acquisitions of assets that are relatively difficult to value.

Note that while the possibility that our results are sample specific cannot be conclusively ruled out, our sample sizes for both subsets are reasonably large. Over the period $[-3,-1]$ months, there are 216 firms with available data in the physical acquisitions subset and 391 firms in the "other" acquisitions subset. The number of firms with available share return data falls away dramatically over the $[0,+36]$ months period but, as noted earlier, this drop-off is unrelated to firm survival and almost wholly due to the lack of share return data beyond December 1999. In any event, the drop-off rate is similar for both subsets.

\subsection{Summary and conclusions}

Asset acquisition frequent and economically significant occurences that, on average, significantly enrich the shareholders of the acquiring firms, at least in the short-term. Acquiring firms are typically firms that have performed exceptionally well in the months leading to announcement of an substantial asset acquisition. The significantly positive market reaction to announcement of news of an asset acquisitions indicates that investors generally agree acquisitions are positive NPV investments. Contrary to what has been widely documented in the existing literature, firms' level of free cash flow is not a relevant variable in explaining the market reaction to announcement of asset acquisitions. That is, asset acquisitions are evidently not seen by investors as being symptomatic of agency problems.

Over the long-term, in the post-announcement period, acquiring firms exhibit abnormally poor performance that is consistent with that widely reported in takeover event-studies. One implication is that the public-auction process that characterises most takeover bids cannot be blamed for acquisitions not adding value because there is no similar auction process in asset acquisitions. The poor performance in the post-acquisition period is principally a function of acquirers of assets that are not solely physical. This suggests that the market finds it difficult to unbiasedly assess the value of these assets. The proposition that sharemarket performance over the long-term is systematically related to the degree of difficulty that investors may experience in

unbiasedly assessing the value of assets is not one that has been previously mooted in the literature. Our study makes an important contribution in documenting evidence consistent with this possiblity.

The above findings contain several significant implications for the research agenda. Research into acquisitive activity by firms has focused almost exclusively on takeover bids. We document 
that the market for acquisitions of substantial assets rivals that of the takeover market and commensurate research is warranted. Our results support the hubris hypothesis but also point to an intriguing connection between type of assets acquired and efficiency in market pricing that has been largely ignored in takeover event-studies. Our results suggest that managerial hubris and market inefficiency in pricing may be systematically related to how difficult it is to value assets that are acquired. Firms that acquire physical assets do not seem subject to hubris and markets are more efficient in pricing these acquisitions than firms that acquire non-physical assets. Further exploration of this hypothesis promises to yield exciting new insights into sharemarket behavior.

\section{References}

Agrawal, A., Jaffe, J.F., Mandelker, G.N., 2000. The post-merger performance puzzle, Advances in Mergers and Acquisitions v1, p. 7-41

Agrawal, A., Jaffe, J.F., Mandelker, G.N., 1992. The post-merger performance of acquiring firms: A re-examination of an anomaly. Journal of Finance 47, 1605-1621.

Asquith, P., 1983. Merger bids, uncertainty, and stockholder returns. Journal of Financial Economics 11, 51-83.

Barber, B.M., Lyon, J., 1997. Detecting Long-Run Abnormal Stock Returns: The Empirical Power and Specification of Test Statistics. Journal of Financial Economics 43, 431-372.

Bellamy, D., Lewin, W., 1991. Corporate takeovers, method of payment, and bidding firms; shareholders returns: Australian evidence. Asia Pacific Journal of Management 9, 137149.

Bishop, S., Dodd, P., Officer, R.R., 1986. Australian Takeovers: The Evidence. The Centre for Independent Studies, St. Leonards, NSW.

Bradley, M., Desai, A., Kim, E.H., 1988. Synergistic gains from corporate acquisitions and their division between the stockholders of target and acquiring firms. Journal of Financial Economics 21, 3-40.

Brailsford, T., Yeoh, D., 2000. An examination of the role of agency costs in capital expenditure announcements. Working paper. The Australian National University, Canberra

Brown, P., Da Silva Rosa, R., 1998. Research method and the long-run performance of acquiring firms. Australian Journal of Management 23, 23-38.

Bugeja, M., Walter, T., 1995. An empirical analysis of some determinants of the target shareholder premium in takeovers. Accounting and Finance 35, 33-60.

Chang, S., 1998. Takeovers of privately held targets, methods of payment, and bidder returns. Journal of Finance 53, 773-784.

Chen, S.S., Ho, K.W., 1997. Market response to product-strategy and capital expenditure announcements in Singapore: Investment opportunities and free cash flow. Financial Management 26, 82-88.

Chung, K., Wright, P., Charoenwong, C., 1998. Investment opportunities and market reaction to capital expenditure decisions. Journal of Banking and Finance 22, 41-60.

Da Silva Rosa, R., 1994, The economic consequences of Australian corporate takeovers, PhD thesis, Department of Accounting and Finance, University of Western Australia.

Da Silva Rosa, R., Izan, H.Y., Steinbeck, A., Walter, T., 2000. The method of payment decision in Australian takeovers: An investigation of causes and effects. Australian Journal of Management 25, 67-94. 
Da Silva Rosa, R., Limmack, R., Supriadi, S., Woodliff. D., 2000. The equity wealth effects of method of payment in takeover bids for privately held firms. Working paper. University of Western Australia

Datta, S., Iskandar-Datta, M.E., 1995. Corporate partial acquisitions, total firm valuation and the effect of financing method. Journal of Banking and Finance 19, 97-115.

Dodd, P. 1980. Merger proposals, management discretion, and stockholder wealth. Journal of Financial Economics 8: 105-137.

Eyssell, T.H., 1989. Partial acquisitions and firm performance. Journal of Economics and Business 41, 69-88.

Fama, E., 1998. Market efficiency, long-term returns, and behavioural finance. Journal of Financial Economics 49, 283-306.

Franks, J.R., Harris, R.S., Titman, S., 1991. The postmerger share price performance of acquiring firms. Journal of Financial Economics 29, 81-96.

Harford, J., 1999. Corporate cash reserves and acquisitions. Journal of Finance 54, 1969-1997.

Jarrell, G.A., Brickley, J.A., Netter, J.M., 1988. The market for corporate control: The empirical evidence since 1980. Journal of Economic Perspective 23, 49-67.

Jensen, M.C, 1986. Agency costs of free cash flow, corporate finance and takeovers. American Economic Review 76, 323-329.

Jensen, M.C. Ruback, R.S., 1983. The market for corporate control: The scientific evidence. Journal of Financial Economics 11, 5-50.

Kothari, S.P., Warner, J., 1997. Measuring Long Horizon Security Price Performance. Journal of Financial Economics 43, 301-339.

Lang, L., Poulsen, A., Stulz, R., 1995. Asset sales, firm performance, and the agency costs of managerial discretion. Journal of Financial Economics 37, 3-37.

Lang, L., Stulz, R., Walkling, R., 1989. Managerial performance, Tobin's q, and the gains from successful tender offers. Journal of Financial Economics 24, 137-154.

Lang, L., Stulz, R., Walkling, R., 1991. A test of free cash flow hypothesis: the case of bidder returns. Journal of Financial Economics 29, 315-336.

Loughran, T., Vijh, A.M., 1997. Do long-term shareholders benefit from corporate acquisitions? Journal of Finance 51, 1765-90.

McConnell, J., Muscarella, C., 1985. Corporate capital expenditure decisions and the market value of the firm. Journal of Financial Economics 14, 339-422.

Morck, R., Shleifer, A., Vishny, R., 1990. Do managerial objectives drive bad acquisitions? Journal of Finance 45, 31-48.

Rau, P.R. and Vermaelen, T, 1998, "Glamour, value and the post-acquisition performance of acquiring firms", Journal of Financial Economics v49:223-253.

Roll, R., 1986. The hubris hypothesis of corporate takeovers. Journal of Business 59, 197-216.

Schwert, G.W., 1996. Markup pricing in mergers and acquisitions. Journal of Financial Economics 41, 153-192

Servaes, H., 1991. Tobin's q and the gains from takeovers. Journal of Finance 46, 409-419.

Smith, R., Kim, J.H., 1994. The combined effects of free cash flow and financial slack on bidder and target stock returns. Journal of Business 67, 281-310.

Szewczyk, S., Testsekos, G., Zantout, Z., 1996. The valuation of corporate R\&D expenditures: Evidence from investment opportunities and free cash flow. Financial Management 25, 105-110.

Walter, T.S., 1984. Australian Takeovers: Capital market efficiency and shareholder risk and returns. Australian Journal of Management 9, 63-118.

Woolridge, R., 1988. Competitive decline and corporate restructuring: is a myopic stock market to blame? Journal of Applied Corporate Finance 1, 26-36. 
Table 1 : Sample Distribution by Year

Time series distribution of substantial asset acquisitions announced each year from January 1990 to December 1999. The full sample consists of all assets acquisitions by an Australian listed firm with a deal value over $\$ 10$ million. Acquisitions of financial assets, companies, businesses or divisions were excluded to derive the pure assets sub-sample. Assets acquired through merger and takeovers are also excluded from this sub-sample. The physical assets sub-sample is a subset of the pure assets sub sample and consists of acquisitions of physical assets, including acquisition of plant, machinery, property, equipment, mine, and shopping centre. Capital expenditures associated with the construction of a physical asset such as a building or new plant are excluded.

\begin{tabular}{|l|c|cc|}
\hline Year & $\begin{array}{c}\text { All Acquisitions } \\
\text { (full sample) }\end{array}$ & $\begin{array}{c}\text { Pure assets } \\
\text { (sub-sample) }\end{array}$ & $\begin{array}{c}\text { Physical Assets } \\
\text { (sub-sample) }\end{array}$ \\
\cline { 3 - 4 } 1990 & 7 & 0 & 0 \\
1991 & 8 & 0 & 0 \\
1992 & 9 & 3 & 3 \\
1993 & 17 & 9 & 6 \\
1994 & 30 & 13 & 9 \\
1995 & 42 & 20 & 11 \\
1996 & 106 & 60 & 37 \\
1997 & 130 & 79 & 46 \\
1998 & 121 & 76 & 66 \\
1999 & 154 & 73 & 47 \\
\hline Total & $\mathbf{6 2 4}$ & $\mathbf{3 3 3}$ & $\mathbf{2 2 5}$ \\
\hline No of Firms & 325 & 184 & 116 \\
\hline
\end{tabular}

Table 2 - Descriptive Statistics

Deal value and relative deal size of asset acquisitions. Deal Value is the total value offered for the assets in millions. It includes cost incidental to the acquisition such as contract costs. Relative Deal Size is calculated by dividing the deal value by the acquiring firm's book value of total assets as obtained from the financial statements immediately prior to announcement date.

\begin{tabular}{|l|c|c|c|}
\hline \multicolumn{2}{|c|}{ All Acquisitions } & Pure assets & Physical Assets \\
Deal Value (\$'000s) & $\mathrm{N}=618$ & $\mathrm{~N}=329$ & $\mathrm{~N}=224$ \\
Mean & 112,654 & 84,691 & 88,258 \\
StdDev & 245,259 & 169,469 & 190,234 \\
Min & 10,000 & 10,000 & 10,000 \\
Median & 40,000 & 36.65 & 40,000 \\
Max & $2,800,000$ & $2,200,000$ & $2,200,000$ \\
Relative Deal Size & $\mathrm{N}=520$ & $\mathrm{~N}=278$ & $\mathrm{~N}=189$ \\
Mean & 0.4555 & 0.5173 & 0.5709 \\
StdDev & 2.2006 & 2.8671 & 3.4331 \\
Min & 0.0001 & 0.0001 & 0.0001 \\
Median & 0.0872 & 0.0974 & 0.0955 \\
Max & 44.7958 & 44.7958 & 44.7958 \\
\hline
\end{tabular}


Table 3 -Announcement Period Returns

Abnormal (market-adjusted) buy-hold announcement returns across various trading day windows expressed relative to the earliest announcement date for substantial asset acquisitions. Student tstatistics, indicating whether the mean return is significantly different from zero, and ' $\mathrm{n}$ ', the total number of observations in each sample, are reported in the parentheses respectively.

\begin{tabular}{|l|c|c|c|}
\hline \multicolumn{1}{|c}{$\begin{array}{c}\text { Return } \\
\text { Window }\end{array}$} & $\begin{array}{c}\text { All Acquisitions } \\
\text { (Full Sample) }\end{array}$ & $\begin{array}{c}\text { Pure assets } \\
\text { (Sub-Sample) }\end{array}$ & $\begin{array}{c}\text { Physical Assets } \\
\text { (Sub-Sample) }\end{array}$ \\
\hline$(-1,0)$ & $0.6150^{* * *}$ & $0.4488^{* *}$ & 0.1847 \\
& $(3.51, \mathrm{n}=622)$ & $(1.98, \mathrm{n}=332)$ & $(0.94, \mathrm{n}=224)$ \\
$(-1,1)$ & $1.0845^{* * *}$ & $0.8513^{* * *}$ & 0.3326 \\
& $(4.57, \mathrm{n}=616)$ & $(2.63, \mathrm{n}=330)$ & $(1.05, \mathrm{n}=222)$ \\
$(-2,2)$ & $1.1989^{* * *}$ & $0.5697^{*}$ & 0.2218 \\
& $(4.56, \mathrm{n}=615)$ & $(1.74, \mathrm{n}=330)$ & $(0.66, \mathrm{n}=222)$ \\
$(-5,5)$ & $1.5248^{* * *}$ & $0.7137^{*}$ & 0.4709 \\
& $(4.23, \mathrm{n}=610)$ & $(1.65, \mathrm{n}=325)$ & $(1.03, \mathrm{n}=217)$ \\
$(-5,1)$ & $1.5931^{* * *}$ & $1.0234^{* * *}$ & $0.8226^{* *}$ \\
& $(5.35, \mathrm{n}=613)$ & $(2.71, \mathrm{n}=328)$ & $(2.16, \mathrm{n}=220)$ \\
$(-10,1)$ & $1.8710^{* * *}$ & $0.8524^{*}$ & 0.4972 \\
& $(5.17, \mathrm{n}=611)$ & $(1.95, \mathrm{n}=327)$ & $(1.10, \mathrm{n}=219)$ \\
$(-10,10)$ & $1.7934 * * *$ & 0.5301 & 0.2039 \\
& $(4.27, \mathrm{n}=608)$ & $(1.00, \mathrm{n}=324)$ & $(0.34, \mathrm{n}=216)$ \\
\hline
\end{tabular}

*** Significant at the .01 level.

** Significant at the .05 level.

*** Significant at the .10 level. 
Table 4 - Announcement Returns by Relative Deal Value

Mean abnormal (market-adjusted) buy-hold announcement returns calculated over various trading day windows relative to the earliest announcement date for the full sample (Panel A) and physical asset sub-sample (Panel B), sorted by relative deal value quartiles.

Panel A: All Acquisitions (Full Sample)

\begin{tabular}{|c|c|c|c|c|}
\hline Return Windows & $(-1,0)$ & $(-1,1)$ & $(-2,2)$ & $(-5,5)$ \\
\hline Highest relative deal value Quartile (N) & 129 & 126 & 126 & 124 \\
\hline Mean BHAR $(\%)$ & $1.596 * * *$ & $2.777 * * *$ & $3.410 * * *$ & $4.074 * * *$ \\
\hline StdDev & 6.469 & 9.256 & 10.292 & 12.370 \\
\hline t-statistic & 2.8016 & 3.3638 & 3.7188 & 3.6675 \\
\hline Second Quartile (N) & 130 & 130 & 130 & 129 \\
\hline Mean BHAR $(\%)$ & 0.393 & $0.854 * *$ & 0.611 & 1.220 \\
\hline StdDev & 3.388 & 4.950 & 6.105 & 10.678 \\
\hline t-statistic & 1.323 & 1.969 & 1.141 & 1.297 \\
\hline Third Quartile (N) & 129 & 129 & 129 & 129 \\
\hline Mean BHAR $(\%)$ & -0.004 & 0.433 & $0.682 *$ & $0.874 *$ \\
\hline StdDev & 2.794 & 3.620 & 4.512 & 5.942 \\
\hline Lowest Relative Deal Value Quartile (N) & 130 & 129 & 129 & 128 \\
\hline Mean BHAR $(\%)$ & 0.237 & 0.329 & 0.208 & -0.139 \\
\hline StdDev & 2.223 & 2.778 & 3.336 & 4.653 \\
\hline t-statistic & 1.217 & 1.347 & 0.707 & -0.338 \\
\hline \multicolumn{5}{|c|}{ Difference in mean BHARs between the highest and lowest quartiles } \\
\hline \multirow{2}{*}{$\begin{array}{l}\mathrm{BHAR}_{\text {highest }}-\mathrm{BHAR}_{\text {lowest }} \\
\text { t-statistic }\end{array}$} & $1.358 * *$ & $2.444 * * *$ & $3.202 * * *$ & $4.213 * * *$ \\
\hline & -2.256 & -2.842 & -3.326 & -3.557 \\
\hline
\end{tabular}

Panel B: Physical Asset Acquisitions (Sub-Sample)

\begin{tabular}{|c|c|c|c|c|}
\hline Return Windows & $(-1,0)$ & $(-1,1)$ & $(-2,2)$ & $(-5,5)$ \\
\hline Highest Relative Deal Value Quartile (N) & 47 & 45 & 45 & 43 \\
\hline Mean BHAR $(\%)$ & $1.028 *$ & 1.523 & 1.704 & $2.442 *$ \\
\hline StdDev & 4.215 & 8.636 & 8.214 & 9.363 \\
\hline t-statistic & 1.672 & 1.183 & 1.392 & 1.710 \\
\hline Second Quartile (N) & 48 & 48 & 48 & 47 \\
\hline Mean BHAR (\%) & -0.372 & -0.389 & $-1.259 * *$ & -1.622 \\
\hline StdDev & 2.088 & 2.484 & 3.699 & 7.105 \\
\hline t-statistic & -1.233 & -1.084 & -2.358 & -1.565 \\
\hline Third Quartiles (N) & 46 & 46 & 46 & 46 \\
\hline Mean BHAR (\%) & $-0.484 *$ & -0.228 & -0.137 & 0.478 \\
\hline StdDev & 1.749 & 2.618 & 3.518 & 4.444 \\
\hline t-statistic & -1.876 & -0.591 & -0.265 & 0.730 \\
\hline Lowest Relative Deal Value Quartile (N) & 47 & 47 & 47 & 46 \\
\hline Mean BHAR (\%) & 0.469 & 0.590 & 0.655 & 0.677 \\
\hline StdDev & 2.446 & 3.238 & 4.140 & 4.898 \\
\hline t-statistic & 1.316 & 1.249 & 1.084 & 0.938 \\
\hline \multicolumn{5}{|c|}{ Difference in mean BHARs between the highest and lowest quartiles } \\
\hline $\mathrm{BHAR}_{\text {highest }}-\mathrm{BHAR}_{\text {lowest }}$ & 0.559 & 0.933 & 1.049 & 1.765 \\
\hline t-statistic & -0.786 & -0.680 & -0.768 & -1.103 \\
\hline
\end{tabular}


Table 5 - Announcement Returns by Growth Opportunities

Mean abnormal (market-adjusted) buy-hold announcement returns calculated over various trading day windows relative to the earliest announcement date for the full sample (Panel A) and physical asset sub-sample (Panel B), sorted by market-to-book quartiles.

Panel A: All Acquisitions (Full Sample)

\begin{tabular}{|c|c|c|c|c|}
\hline Return Windows & $(-1,0)$ & $(-1,1)$ & $(-2,2)$ & $(-5,5)$ \\
\hline Highest Market-to-Book Quartile (N) & 106 & 106 & 106 & 105 \\
\hline Mean BHAR $(\%)$ & 0.322 & 0.326 & $1.323 * *$ & 1.345 \\
\hline StdDev & 3.083 & 4.475 & 5.785 & 8.561 \\
\hline t-statistic & 1.077 & 0.749 & 2.354 & 1.610 \\
\hline Second Quartile (N) & 106 & 104 & 104 & 104 \\
\hline Mean BHAR (\%) & 0.473 & $0.917 * *$ & $1.380 * *$ & 1.184 \\
\hline StdDev & 3.265 & 4.047 & 6.941 & 9.361 \\
\hline t-statistic & 1.490 & 2.310 & 2.027 & 1.290 \\
\hline Third Quartile (N) & 106 & 105 & 105 & 105 \\
\hline Mean BHAR (\%) & 0.164 & $1.023 * *$ & 0.503 & 0.691 \\
\hline StdDev & 3.083 & 5.270 & 5.865 & 6.442 \\
\hline t-statistic & 0.548 & 1.990 & 0.879 & 1.099 \\
\hline Lowest Market-to-Book Quartiles (N) & 105 & 104 & 104 & 101 \\
\hline Mean BHAR (\%) & $1.170^{*}$ & $2.472 * * *$ & $2.090 * *$ & $3.340 * * *$ \\
\hline StdDev & 6.127 & 8.541 & 8.652 & 11.956 \\
\hline t-statistic & 1.958 & 2.951 & 2.463 & 2.808 \\
\hline \multicolumn{5}{|c|}{ Difference in mean BHARs between the highest and lowest market-to-book ratio quartiles } \\
\hline $\mathrm{BHAR}_{\text {highest }}-\mathrm{BHAR}_{\text {lowest }}$ & -0.848 & $-2.146 * *$ & -0.767 & -1.995 \\
\hline t-statistic & 1.268 & 2.275 & 0.753 & 1.372 \\
\hline \multicolumn{5}{|c|}{ Panel B: Physical Asset Acquisitions (Sub-Sample) } \\
\hline Return Windows & $(-1,0)$ & $(-1,1)$ & $(-2,2)$ & $(-5,5)$ \\
\hline Highest Market-to-Book Quartiles (N) & 36 & 36 & 36 & 35 \\
\hline Mean BHAR (\%) & -0.330 & -0.945 & -0.459 & -1.463 \\
\hline StdDev & 2.722 & 3.918 & 5.679 & 7.993 \\
\hline t-statistic & -0.728 & -1.447 & -0.485 & -1.083 \\
\hline Second Quartile (N) & 36 & 34 & 34 & 34 \\
\hline Mean BHAR (\%) & -0.006 & -0.140 & -0.619 & -0.061 \\
\hline StdDev & 1.713 & 1.890 & 3.094 & 3.807 \\
\hline t-statistic & -0.023 & -0.433 & -1.167 & -0.094 \\
\hline Third Quartile (N) & 36 & 36 & 36 & 36 \\
\hline Mean BHAR (\%) & -0.248 & -0.119 & -0.454 & -0.568 \\
\hline StdDev & 1.999 & 2.674 & 3.304 & 4.328 \\
\hline t-statistic & -0.743 & -0.268 & -0.824 & -0.788 \\
\hline Lowest Market-to-Book Quartiles (N) & 34 & 34 & 34 & 31 \\
\hline Mean BHAR (\%) & 0.686 & 2.102 & 1.387 & 2.450 \\
\hline StdDev & 4.500 & 9.231 & 8.993 & 9.503 \\
\hline t-statistic & 0.8884 & 1.3276 & 0.8991 & 1.4354 \\
\hline \multicolumn{5}{|c|}{ Difference in mean BHARs between the highest and lowest market-to-book ratio quartiles } \\
\hline $\mathrm{BHAR}_{\text {highest }}-\mathrm{BHAR}_{\text {lowest }}$ & -10152 & $-3.0465^{*}$ & -1.8454 & $-3.9124 *$ \\
\hline t-statistic & 1.1345 & 1.7790 & 1.0198 & 1.7973 \\
\hline
\end{tabular}

Market-to-Book is the firms' market capitalisation three months prior to announcement divided by the book value of equity for the last financial period prior to announcement.

*** Significant at the .01 level.

** Significant at the .05 level.

* Significant at the .10 level. 
Table 6 - Announcement Returns by Undistributed Cash Flows

Mean abnormal (market-adjusted) buy-hold announcement returns and the differences between mean BHARs calculated over various trading day windows relative to the earliest announcement date for the full sample (Panel A) and physical asset sub-sample (Panel B), sorted by undistributed cash flow quartiles. Undistributed cash flow is defined as operating income before depreciation minus interest expense, taxes, and dividends, scaled by total assets.

Panel A: All Acquisitions (Full Sample)

\begin{tabular}{|c|c|c|c|c|}
\hline Return Windows & $(-1,0)$ & $(-1,1)$ & $(-2,2)$ & $(-5,5)$ \\
\hline Highest Undistributed CF Quartiles (N) & 130 & 128 & 128 & 128 \\
\hline Mean BHAR $(\%)$ & $0.6694 * *$ & $1.1904 * * *$ & $1.1051 *$ & $2.0755 * *$ \\
\hline StdDev & 3.9263 & 4.9692 & 6.9539 & 9.8996 \\
\hline t-statistic & 1.9439 & 2.7103 & 1.7979 & 2.3720 \\
\hline Second Quartile (N) & 129 & 127 & 127 & 127 \\
\hline Mean BHAR (\%) & 0.4157 & $1.3888 * * *$ & $1.5678 * * *$ & 0.7560 \\
\hline StdDev & 3.0492 & 4.8159 & 5.4206 & 7.4029 \\
\hline t-statistic & 1.5484 & 3.2499 & 3.2595 & 1.1509 \\
\hline Third Quartile (N) & 130 & 130 & 130 & 130 \\
\hline Mean BHAR (\%) & 0.4810 & $1.1788 * * *$ & $1.3555 * *$ & $1.3498 * *$ \\
\hline StdDev & 3.8091 & 5.3327 & 6.7254 & 7.0834 \\
\hline t-statistic & 1.4399 & 2.5204 & 2.2980 & 2.1727 \\
\hline Lowest Undistributed CF Quartiles & 128 & 128 & 128 & 124 \\
\hline Mean BHAR (\%) & 0.6893 & 0.6760 & 0.8714 & $2.0135 * *$ \\
\hline StdDev & 5.3257 & 7.5594 & 7.5440 & 11.4640 \\
\hline t-statistic & 1.4643 & 1.0117 & 1.3068 & 1.9559 \\
\hline \multicolumn{5}{|c|}{ Difference in mean BHARs between the highest and lowest Undistributed CF ratio quartiles } \\
\hline $\mathrm{BHAR}_{\text {highest }}-\mathrm{BHAR}_{\text {lowest }}$ & -0.0199 & 0.5144 & 0.2336 & 0.0620 \\
\hline t-statistic & 0.0340 & -0.6433 & -0.2576 & -0.0459 \\
\hline
\end{tabular}

Panel B: Physical Asset Acquisitions (Sub-Sample)

\begin{tabular}{|c|c|c|c|c|}
\hline Return Windows & $(-1,0)$ & $(-1,1)$ & $(-2,2)$ & $(-5,5)$ \\
\hline Highest Undistributed CF Quartiles (N) & 45 & 43 & 43 & 43 \\
\hline Mean BHAR $(\%)$ & -0.3399 & -0.0547 & -0.8095 & -1.1417 \\
\hline StdDev & 2.4946 & 2.7801 & 5.0407 & 6.5504 \\
\hline t-statistic & -0.9141 & -0.1290 & -1.0530 & -1.1429 \\
\hline Second Quartile (N) & 47 & 47 & 47 & 47 \\
\hline Mean BHAR (\%) & 0.2244 & 0.6696 & 0.7341 & 1.4366 \\
\hline StdDev & 2.8131 & 3.7174 & 4.8870 & 6.3207 \\
\hline t-statistic & 0.5468 & 1.2348 & 1.0298 & 1.5582 \\
\hline Third Quartile (N) & 47 & 47 & 47 & 46 \\
\hline Mean BHAR (\%) & 0.2386 & 0.0251 & -0.3431 & 0.4870 \\
\hline StdDev & 2.0066 & 2.6221 & 3.9498 & 5.8759 \\
\hline t-statistic & 0.8153 & 0.0657 & -0.5955 & 0.5622 \\
\hline Lowest Undistributed CF Quartiles (N) & 46 & 46 & 46 & 43 \\
\hline Mean BHAR $(\%)$ & 0.4143 & 0.7035 & 1.0914 & 0.8888 \\
\hline StdDev & 3.7223 & 8.2792 & 6.8950 & 8.3578 \\
\hline t-statistic & 0.7549 & 0.5763 & 1.0736 & 0.6973 \\
\hline \multicolumn{5}{|c|}{ Difference in mean BHARs between the highest and lowest Undistributed CF ratio quartiles } \\
\hline $\mathrm{BHAR}_{\text {highest }}-\mathrm{BHAR}_{\text {lowest }}$ & -0.7542 & -0.7582 & -1.9009 & -2.0305 \\
\hline t-statistic & 1.1377 & 0.5867 & 1.4915 & 1.2539 \\
\hline
\end{tabular}




\section{Table 7 - Announcement Returns by Market-to-Book and Undistributed Cash Flow}

Mean abnormal (market-adjusted) buy-hold announcement returns for the full sample (Panel A) and the physical asset sub-sample (Panel B). The value in each cell is mean BHAR over the ($5,+5)$ day window relative to the announcement date. Observations are grouped according to the market-to-book ratio and the scaled cash flow ratio (cash flow divided by total assets). Low cash flow firms are firms with cash flow ratio of less than the sample median. Firms with a market-tobook ratio of less than 1 is classified as low market-to-book firms. Student t-statistics, indicating whether the mean return is significantly different from zero, are reported in the parentheses along with the number of observations.

Panel A: All Acquisitions (Full Sample)

\begin{tabular}{|l|c|c|}
\hline \multirow{2}{*}{ Cash Flow } & \multicolumn{2}{|c|}{ Market-to-Book } \\
\cline { 2 - 3 } High & Low & High \\
& $4.988^{*}$ & 0.975 \\
& $(1.861, \mathrm{n}=25)$ & $(1.545, \mathrm{n}=180)$ \\
\hline Low & $3.406^{* *}$ & $1.176701^{*}$ \\
& $(2.312, \mathrm{n}=65)$ & $(1.746, \mathrm{n}=139)$ \\
\hline
\end{tabular}

Panel C: Physical Asset Acquisitions (Sub-Sample)

\begin{tabular}{|l|c|c|}
\hline \multirow{2}{*}{ Cash Flow } & \multicolumn{2}{|c|}{ Market-to-Book } \\
\cline { 2 - 3 } High & Low & High \\
& 1.934 & -1.092 \\
& $(1.129, \mathrm{n}=19)$ & $(-1.171, \mathrm{n}=49)$ \\
\hline Low & 0.835 & -0.187 \\
& $(0.466, \mathrm{n}=26)$ & $(-0.239, \mathrm{n}=40)$ \\
\hline
\end{tabular}

Market-to-Book ratio is defined in this table as MB3 (calculated as firms' market capitalisation three months prior to announcement divided by the book value of equity for the last financial period prior to announcement)

*** Significant at the .01 level.

** Significant at the .05 level.

* Significant at the .10 level 
Table 8 - Long-run abnormal returns

Abnormal (market-adjusted) buy-hold announcement returns for various trading windows expressed in months relative to the announcement month. Cumret is the average buy-and-hold return to the sample firms. Emktadj is the average market adjusted return to sample of firms, where the market portfolio is equal-weighted. Vmktadj is the average market adjusted return to sample of firms, where the market portfolio is value-weighted. Decadj is the average decile adjusted return to sample firms, where the return to the decile to which the sample firm belongs is calculated on an equal-weighted basis. Number is the number of sample firms with available data over the event-window

Panel A: All Acquisitions (Full Sample)

\begin{tabular}{|c|c|c|c|c|c|}
\hline $\begin{array}{l}\text { Return } \\
\text { Window }\end{array}$ & cumret & emktadj & vmktadj & decadj & Number \\
\hline$[-18,-1]$ & $32.26 \%$ & $12.95 \%$ & $24.31 \%$ & $23.17 \%$ & 554 \\
\hline$[-12,-1]$ & $21.50 \%$ & $7.37 \%$ & $16.14 \%$ & $14.98 \%$ & 573 \\
\hline$[-6,-1]$ & $8.70 \%$ & $1.35 \%$ & $5.94 \%$ & $5.58 \%$ & 594 \\
\hline$[-3,-1]$ & $3.21 \%$ & $0.74 \%$ & $2.41 \%$ & $2.27 \%$ & 607 \\
\hline$[-1,+1]$ & $2.32 \%$ & $0.27 \%$ & $1.98 \%$ & $2.06 \%$ & 587 \\
\hline$[0,+3]$ & $1.26 \%$ & $-2.11 \%$ & $0.18 \%$ & $0.38 \%$ & 557 \\
\hline$[0,+6]$ & $2.76 \%$ & $-3.91 \%$ & $0.13 \%$ & $0.84 \%$ & 523 \\
\hline$[0,+12]$ & $2.12 \%$ & $-7.56 \%$ & $-3.25 \%$ & $-0.66 \%$ & 441 \\
\hline$[0,+24]$ & $6.81 \%$ & $-6.73 \%$ & $-3.01 \%$ & $2.08 \%$ & 299 \\
\hline$[0,+36]$ & $9.80 \%$ & $-32.02 \%$ & $-6.77 \%$ & $-5.43 \%$ & 166 \\
\hline & \multicolumn{5}{|c|}{ Panel B: Physical Acquisitions (Sub-Sample) } \\
\hline $\begin{array}{l}\text { Return } \\
\text { Window }\end{array}$ & cumret & emktadj & vmktadj & decadj & Number \\
\hline$[-18,-1]$ & $27.08 \%$ & $13.62 \%$ & $19.22 \%$ & $20.50 \%$ & 192 \\
\hline$[-12,-1]$ & $14.03 \%$ & $4.75 \%$ & $8.99 \%$ & $9.72 \%$ & 202 \\
\hline$[-6,-1]$ & $9.19 \%$ & $3.84 \%$ & $6.50 \%$ & $6.90 \%$ & 212 \\
\hline$[-3,-1]$ & $2.78 \%$ & $0.94 \%$ & $1.91 \%$ & $2.07 \%$ & 216 \\
\hline$[-1,+1]$ & $2.09 \%$ & $0.33 \%$ & $1.64 \%$ & $1.99 \%$ & 210 \\
\hline$[0,+3]$ & $1.96 \%$ & $-0.91 \%$ & $0.87 \%$ & $1.15 \%$ & 205 \\
\hline$[0,+6]$ & $4.18 \%$ & $-2.37 \%$ & $1.35 \%$ & $1.82 \%$ & 199 \\
\hline$[0,+12]$ & $5.54 \%$ & $-4.49 \%$ & $0.38 \%$ & $2.58 \%$ & 168 \\
\hline$[0,+24]$ & $14.72 \%$ & $5.29 \%$ & $4.67 \%$ & $10.78 \%$ & 99 \\
\hline$[0,+36]$ & $12.11 \%$ & $-13.82 \%$ & $-3.49 \%$ & $0.40 \%$ & 54 \\
\hline
\end{tabular}


Panel C: Other (Non-Physical) Acquisitions (Sub-Sample)

\begin{tabular}{|c|c|c|c|c|c|}
\hline \multicolumn{2}{|c|}{$\begin{array}{c}\text { Return } \\
\text { Window }\end{array}$} & emktadj & vmktadj & decadj & Number \\
$(-18,-1)$ & $35.01 \%$ & $12.59 \%$ & $27.01 \%$ & $24.58 \%$ & 362 \\
$(-12,-1)$ & $25.29 \%$ & $8.62 \%$ & $19.77 \%$ & $17.66 \%$ & 371 \\
$(-6,-1)$ & $8.43 \%$ & $-0.03 \%$ & $5.63 \%$ & $4.85 \%$ & 382 \\
$(-3,-1)$ & $3.45 \%$ & $0.62 \%$ & $2.69 \%$ & $2.38 \%$ & 391 \\
$(-1,+1)$ & $2.45 \%$ & $0.24 \%$ & $2.17 \%$ & $2.11 \%$ & 377 \\
$(0,+3)$ & $0.85 \%$ & $-2.81 \%$ & $-0.22 \%$ & $-0.07 \%$ & 351 \\
$(0,+6)$ & $1.89 \%$ & $-4.86 \%$ & $-0.62 \%$ & $0.24 \%$ & 324 \\
$(0,+12)$ & $0.01 \%$ & $-9.46 \%$ & $-5.49 \%$ & $-2.66 \%$ & 272 \\
$(0,+24)$ & $2.90 \%$ & $-12.68 \%$ & $-6.81 \%$ & $-2.23 \%$ & 200 \\
$(0,+36)$ & $8.69 \%$ & $-40.79 \%$ & $-8.35 \%$ & $-8.24 \%$ & 112 \\
\hline
\end{tabular}

